\title{
Respons Imun Terhadap Infeksi Bakteri
}

\author{
Zakiudin Munasir
}

Guna menjaga integritas dan identitas individu diperlukan suatu sistem pertahanan tubuh yang adekuat. Mekanisme imunitas terhadap antigen yang berbahaya meliputi pertahanan fisik dan kimiawi, simbiosis dengan bakteri flora normal, innate immunity serta imunitas spesifik yang didapat, terdiri dari imunitas humoral serta imunitas selular (cell mediated immunity). Antigen Major Histo Compatibility (MHC) berperan pada presentasi antigen oleh makrofag. Respons imun terhadap bakteri meliputi bakteri ekstra seluler dan intra selular. Pada infeksi bakteri yang berat dapat terjadi kelelahan respons imun (exchaustion), dalam keadaan ini pemberian terapi penunjang imunoglobulin intra vena dapat dipertimbangkan.

Kata kunci: innate immunity, humoral immunity, cell mediated immunity, major histo compatibility

S istem imun merupakan sistem koordinasi respons biologik yang bertujuan melindungi integritas dan identitas individu serta mencegah invasi organisme dan zat yang berbahaya di lingkungan yang dapat merusak dirinya.

Sistem imun mempunyai sedikitnya 3 fungsi utama. Yang pertama adalah suatu fungsi yang sangat spesifik yaitu kesanggupan untuk mengenal dan membedakan berbagai molekul target sasaran dan juga mempunyai respons yang spesifik. Fungsi kedua adalah kesanggupan membedakan antara antigen diri dan antigen asing. Fungsi ketiga adalah fungsi memori yaitu kesanggupan melalui pengalaman kontak sebelumnya dengan zat asing patogen untuk bereaksi lebih cepat dan lebih kuat daripada kontak pertama.

\section{Mekanisme Imunitas terhadap Antigen yang Berbahaya}

Ada beberapa mekanisme pertahanan tubuh dalam

Alamat korespondensi:

Dr. Zakiudin Munasir, Sp.A(K).

Subbagian Alergi-Imunologi. Bagian Ilmu Kesehatan Anak FKUIRSCM, Jakarta. Jl. Salemba no. 6, Jakarta 10430.

Tel. 021-316 1144, Fax. 3907743. mengatasi agen yang berbahaya di lingkungannya yaitu:

1. Pertahanan fisik dan kimiawi: kulit, sekresi asam lemak dan asam laktat melalui kelenjar keringat dan sebasea, sekresi lendir, pergerakan silia, sekresi airmata, air liur, urin, asam lambung serta lisosim dalam airmata.

2. Simbiosis dengan bakteri flora normal yang memproduksi zat yang dapat mencegah invasi mikroorganisme seperti laktobasilus pada epitel organ.

3. Innate immunity.

4. Imunitas spesifik yang didapat.

\section{Innate Immunity}

Merupakan mekanisme pertahanan tubuh nonspesifik yang mencegah masuknya dan menyebarnya mikroorganisme dalam tubuh serta mencegah terjadinya kerusakan jaringan. Ada beberapa komponen innate immunity yaitu

1. Pemusnahan bakteri intraselular oleh sel polimorfonuklear (PMN) dan makrofag.

2. Aktivasi komplemen melalui jalur alternatif.

3. Degranulasi sel mast yang melepaskan mediator inflamasi.

4. Protein fase akut: $C$-reactive protein (CRP) yang 
mengikat mikroorganisme, selanjutnya terjadi aktivasi komplemen melalui jalur klasik yang menyebabkan lisis mikroorganisme.

5. Produksi interferon alfa (IFN $\alpha$ ) oleh leukosit dan interferon beta (IFN $\beta$ ) oleh fibroblast yang mempunyai efek antivirus.

6. Pemusnahan mikroorganisme ekstraselular oleh sel natural killer (sel NK) melalui pelepasan granula yang mengandung perforin.

7. Pelepasan mediator eosinofil seperti major basic protein (MBP) dan protein kationik yang dapat merusak membran parasit.

\section{Imunitas Spesifik Didapat}

Bila mikroorganisme dapat melewati pertahanan nonspesifik/innate immunity, maka tubuh akan membentuk mekanisme pertahanan yang lebih kompleks dan spesifik. Mekanisme imunitas ini memerlukan pengenalan terhadap antigen lebih dulu. Mekanisme imunitas spesifik ini terdiri dari:

1. Imunitas humoral

Produksi antibodi spesifik oleh sel limfosit B (T dependent dan non $\mathrm{T}$ dependent).

2. Cell mediated immunity (CMI)

Sel limfosit $\mathrm{T}$ berperan pada mekanisme imunitas ini melalui:

1. Produksi sitokin serta jaringan interaksinya.

2. Sel sitotoksik matang di bawah pengaruh interleukin 2 (IL-2) dan interleukin 6 (IL-6).

\section{Prosesi dan Presentasi Antigen}

Respons imun tubuh dipicu oleh masuknya antigen/ mikroorganisme ke dalam tubuh dan dihadapi oleh sel makrofag yang selanjutnya akan berperan sebagai antigen presenting cell (APC). Sel ini akan menangkap sejumlah kecil antigen dan diekspresikan ke permukaan sel yang dapat dikenali oleh sel limfosit $\mathrm{T}$ penolong (Th atau T helper). Sel Th ini akan teraktivasi dan (selanjutnya sel Th ini) akan mengaktivasi limfosit lain seperti sel limfosit B atau sel limfosit T sitotoksik. Sel $\mathrm{T}$ sitotoksik ini kemudian berpoliferasi dan mempunyai fungsi efektor untuk mengeliminasi antigen. Setiap prosesi ini sel limfosit dan sel APC bekerja sama melalui kontak langsung atau melalui sekresi sitokin regulator. Sel-sel ini dapat juga berinteraksi secara simultan dengan sel tipe lain atau dengan komponen komplemen, kinin atau sistem fibrinolitik yang menghasilkan aktivasi fagosit, pembekuan darah atau penyembuhan luka. Respons imun dapat bersifat lokal atau sistemik dan akan berhenti bila antigen sudah berhasil dieliminasi melalui mekanisme kontrol.

\section{Peran Major Histocompatibility Antigen (MHC)}

Telah disebutkan di atas bahwa respons imun terhadap sebagian besar antigen hanya dimulai bila antigen telah ditangkap dan diproses serta dipresentasikan oleh sel APC. Oleh karena itu sel T hanya mengenal imunogen yang terikat pada protein MHC pada permukaan sel lain. Ada 2 kelas MHC yaitu

1. Protein MHC kelas I. Diekspresikan oleh semua tipe sel somatik dan digunakan untuk presentasi antigen kepada sel TCD8 yang sebagian besar adalah sel sitotoksik. Hampir sebagian besar sel mempresentasikan antigen ke sel T sitotoksik (sel Tc) serta merupakan target/sasaran dari sel Tc tersebut.

2. Protein MHC kelas II. Diekspresikan hanya oleh makrofag dan beberapa sel lain untuk presentasi antigen kepada sel TCD4 yang sebagian besar adalah sel $\mathrm{T}$ helper (Th). Aktivasi sel Th ini diperlukan untuk respons imun yang sesungguhnya dan sel APC dengan MHC kelas II merupakan poros penting dalam mengontrol respons imun tersebut.

\section{Respons Imun terhadap Bakteri Ekstraselular}

Bakteri ekstraselular dapat menimbulkan penyakit melalui beberapa mekanisme yaitu

1. Merangsang reaksi inflamasi yang menyebabkan destruksi jaringan di tempat infeksi. Sebagai contoh misalnya kokus piogenik yang sering menimbulkan infeksi supuratif yang hebat.

2. Produksi toksin yang menghasilkan berbagai efek patologik. Toksin dapat berupa endotoksin dan eksotoksin. Endotoksin yang merupakan komponen dinding bakteri adalah suatu lipopolisakarida yang merupakan stimulator produksi sitokin yang kuat, suatu ajuvan serta aktivator 
poliklonal sel limfosit B. Sebagian besar eksotoksin mempunyai efek sitotoksik dengan mekanisme yang belum jelas benar. Sebagai contoh toksin difteri menghambat sintesis protein secara enzimatik serta menghambat faktor elongasi-2 yang diperlukan untuk sintesis semua peptida. Toksin kolera merangsang sintesis AMP siklik (cAMP) oleh sel epitel usus yang menyebabkan sekresi aktif klorida, kehilangan cairan serta diare yang hebat. Toksin tetanus merupakan suatu neurotoksin yang terikat motor endplate pada neuromuscular junction yang menyebabkan kontraksi otot persisten yang sangat fatal bila mengenai otot pernapasan. Toksin klostridium dapat menyebabkan nekrosis jaringan yang dapat menghasilkan gas gangren. Respons imun terhadap bakteri ekstraselular ditujukan untuk eliminasi bakteri serta netralisasi efek toksin.

\section{Imunitas Alamiah terhadap Bakteri Ekstraselular}

Respons imun alamiah terhadap bakteri ekstraselular terutama melalui mekanisme fagositosis oleh neutrofil, monosit serta makrofag jaringan. Resistensi bakteri terhadap fagositosis dan penghancuran dalam makrofag menunjukkan virulensi bakteri. Aktivasi komplemen tanpa adanya antibodi juga memegang peranan penting dalam eliminasi bakteri ekstraselular. Lipopolisakarida (LPS) dalam dinding bakteri gram negatif dapat mengaktivasi komplemen jalur alternatif tanpa adanya antibodi. Salah satu hasil aktivasi komplemen ini yaitu C3b mempunyai efek opsonisasi bakteri serta meningkatkan fagositosis. Selain itu terjadi lisis bakteri melalui membrane attack complex (MAC) serta beberapa hasil sampingan aktivasi komplemen dapat menimbulkan respons inflamasi melalui pengumpulan (recruitment) serta aktivasi leukosit.

Endotoksin yang merupakan LPS merangsang produksi sitokin oleh makrofag serta sel lain seperti endotel vaskular. Beberapa jenis sitokin tersebut antara lain tumour necrosis factor (TNF), IL-1, IL-6 serta beberapa sitokin inflamasi dengan berat molekul rendah yang termasuk golongan IL-8.

Fungsi fisiologis yang utama dari sitokin yang dihasilkan oleh makrofag adalah merangsang inflamasi non-spesifik serta meningkatkan aktivasi limfosit spesifik oleh antigen bakteri. Sitokin akan menginduksi adhesi neutrofil dan monosit pada endotel vaskular pada tempat infeksi yang diikuti migrasi, akumulasi lokal serta aktivasi sel inflamasi. Kerusakan jaringan yang terjadi adalah akibat efek samping mekanisme pertahanan untuk eliminasi bakteri tersebut. Sitokin juga merangsang demam dan sintesis protein fase akut. Banyak fungsi sitokin yang sama yaitu sebagai ko-stimulator sel limfosit $\mathrm{T}$ dan $\mathrm{B}$ yang menghasilkan mekanisme amplifikasi untuk imunitas spesifik. Sitokin dalam jumlah besar atau produknya yang tidak terkontrol dapat membahayakan tubuh serta berperan dalam menifestasi klinik infeksi bakteri ekstraselular. Yang paling berat adalah gejala klinis oleh infeksi bakteri Gram-negatif yang menyebabkan disseminated intravascular coagulation (DIC) yang progresif serta syok septik atau syok endotoksin. Sitokin TNF adalah mediator yang paling berperan pada syok endotoksin ini.

\section{Imunitas Spesifik terhadap Bakteri Ekstraselular}

Kekebalan humoral mempunyai peran penting dalam respons kekebalan spesifik terhadap bakteri ekstraselular. Lipopolisakarida merupakan komponen yang paling imunogenik dari dinding sel atau kapsul mikroorganisme serta merupakan antigen yang thymus independent. Antigen ini dapat langsung merangsang sel limfosit B yang menghasilkan imunoglobin (Ig)M spesifik yang kuat. Selain itu produksi IgG juga dirangsang yang mungkin melalui mekanisme perangsangan isotype switching rantai berat oleh sitokin.

Respons sel limfosit $T$ yang utama terhadap bakteri ekstraselular melalui sel TCD4 yang berhubungan dengan molekul MHC kelas II yang mekanismenya telah dijelaskan di atas. Sel TCD4 berfungsi sebagai sel penolong untuk merangsang pembentukan antibodi, aktivasi fungsi fagosit dan mikrobisid makrofag.

Ada 3 mekanisme efektor yang dirangsang oleh IgG dan IgM serta antigen permukaan bakteri

1. Opsonisasi bakteri oleh IgG serta peningkatan fagositosis dengan mengikat reseptor $\mathrm{Fc}_{-}$pada monosit, makrofag dan neutrofil. Antibodi IgG dan IgM mengaktivasi komplemen jalur klasik yang menghasilkan $\mathrm{C} 3 \mathrm{~b}$ dan $\mathrm{iC} 3 \mathrm{~b}$ yang mengikat reseptor komplemen spesifik tipe 1 dan tipe 3 dan selanjutnya terjadi peningkatan fagositosis. Pasien defisiensi C3 sangat rentan terhadap infeksi piogenik yang hebat.

2. Netralisasi toksin bakteri oleh IgM dan IgG untuk 
mencegah penempelan terhadap sel target serta meningkatkan fagositosis untuk eliminasi toksin tersebut.

3. Aktivasi komplemen oleh IgM dan IgG untuk menghasilkan mikrobisid MAC serta pelepasan mediator inflamasi akut.

\section{Respons Imun terhadap Bakteri Intraselular}

Sejumlah bakteri dan semua virus serta jamur dapat lolos dan mengadakan replikasi di dalam sel pejamu. Yang paling patogen di antaranya adalah yang resisten terhadap degradasi dalam makrofag. Sebagai contoh adalah mikrobakteria serta Listeria monocytogenes.

\section{Imunitas Alamiah terhadap Bakteri Intraselular}

Mekanisme terpenting imunitas alamiah terhadap mikroorganisme intraselular adalah fagositosis. Akan tetapi bakteri patogen intraselular relatif resisten terhadap degradasi dalam sel fagosit mononuklear. Oleh karena itu mekanisme kekebalan alamiah ini tidak efektif dalam mencegah penyebaran infeksi sehingga sering menjadi kronik dan eksaserbasi yang sulit diberantas.

\section{Respons Imun Spesifik terhadap Bakteri Intraselular}

Respons imun spesifik terhadap bakteri intraselular terutama diperankan oleh cell mediated immunity (CMI). Mekanisme imunitas ini diperankan oleh sel limfosit $T$ tetapi fungsi efektornya untuk eliminasi bakteri diperani oleh makrofag yang diaktivasi oleh sitokin yang diproduksi oleh sel $\mathrm{T}$ terutama interferon $\alpha($ IFN $\alpha)$. Respons imun ini analog dengan reaksi hipersensitivitas tipe lambat.

Antigen protein intraselular merupakan stimulus kuat sel limfosit T. Beberapa dinding sel bakteri mengaktivasi makrofag secara langsung sehingga mempunyai fungsi sebagai ajuvan. Misalnya muramil dipeptida pada dinding sel mikrobakteria.

Telah disebutkan di atas bahwa fungsi sel limfosit $T$ pada CMI adalah produksi sitokin terutama IFN $\alpha$. Sitokin INF $\alpha$ ini akan mengaktivasi makrofag termasuk makrofag yang terinfeksi untuk membunuh bakteri. Beberapa bakteri ada yang resisten sehingga menimbulkan stimulasi antigen yang kronik. Keadaan ini akan menimbulkan pengumpulan lokal makrofag yang teraktivasi yang membentuk granuloma sekeliling mikroorganisme untuk mencegah penyebarannya. Reaksi inflamasi seperti ini berhubungan dengan nekrosis jaringan serta fibrosis yang luas yang menyebabkan gangguan fungsi yang berat. Jadi kerusakan jaringan ini disebabkan terutama oleh respons imun terhadap infeksi oleh beberapa bakteri intraselular. Contoh yang jelas dalam hal ini adalah infeksi mikobakterium. Mikobakterium tidak memproduksi toksin atau enzim yang secara langsung merusak jaringan yang terinfeksi. Paparan pertama terhadap Mycobacterium tuberculosis akan merangsang inflamasi selular lokal dan bakteri mengadakan proliferasi dalam sel fagosit. Sebagian ada yang mati dan sebagian ada yang tinggal dormant. Pada saat yang sama, pada individu yang terinfeksi terbentuk imunitas sel $T$ yang spesifik. Setelah terbentuk imunitas, reaksi granulomatosa dapat terjadi pada lokasi bakteri persisten atau pada paparan bakteri berikutnya. Jadi imunitas perlindungan dan reaksi hipersensitif yang menyebabkan kerusakan jaringan adalah manifestasi dalam respons imun spesifik yang sama.

\section{Terapi Imunoglobulin pada Infeksi}

Pada keadaan infeksi bakteri yang berat, dapat terjadi kelelahan respons imun (exhaustion) pada individu yang mempunyai respons imun yang normal dan keadaan ini dapat terjadi pelepasan berbagai mediator yang merangsang timbulnya syok septik. Dalam keadaan ini terapi penunjang dengan intravenous immunoglobuline (IVIG) dapat diberikan. Terapi IVIG ini secara pasif untuk membantu sistem imun tubuh dengan antibodi yang spesifik terhadap bakteri serta eksotoksin dan endotoksin yang sesuai. Distribusi subkelas IgG harus mirip seperti dalam plasma normal dan sanggup memicu eliminasi antigen secara imunologik. Pemberian IVIG dosis tinggi harus dilakukan dalam jangka pendek tanpa risiko penekanan terhadap sistem imun endogen.

Terdapat 2 jenis preparat IVIG yaitu yang dipecah oleh plasmin dan yang dipecah oleh pepsin.

- Plasmin memecah molekul IgG 7S pada tempat spesifik yaitu pada ikatan disulfida pada tempat CHI yang berseberangan dari rantai berat. Keadaan ini akan melepaskan 2 fragmen Fab bebas dan satu fragmen Fc. Efek aktivasi komplemen 
tidak bertahan lama tetapi meninggalkan efek imunosupresif. Oleh karena itu sering digunakan pada terapi penyakit autoimun. Hanya IgG 2 yang resisten terhadap plasma sehingga masih mengandung sekitar 25\% IgG 2 .

- Enzim pepsin memecah keempat subkelas IgG pada sisi di bawah ikatan disulfida kedua rantai berat molekul imunoglobulin. Pemecahan oleh pepsin ini menghasilkan fragmen IgG dengan 2 rantai pengikat antigen yang masih berhubungan dengan ikatan disulfida yang disebut Fab2. Fragmen Fc-nya dengan cepat dimetabolisme sebagai polipeptida dan diekskresi melalui ginjal sehingga tidak mempunyai peran imunologi lagi. Oleh karena itu, preparat IVIG ini bebas dari fragmen Fc sehingga tidak menyebabkan supresi sistem imun endogen. Preparat IVIG yang hanya mengandung 2 fragmen $F(a b) 2$ akan migrasi ke regio $5 \mathrm{~S}$ pada sentrifugasi, mempunyai indikasi khusus dalam situasi klinis pada saat sistem imun mengalami kelelahan karena infeksi akut yang berat. Oleh karena itu pengobatan IVIG $5 \mathrm{~S}$ dosis tinggi diperlukan untuk menunjang mekanisme kekebalan pada pasien yang mengalami gangguan imuntas. Dibandingkan dengan IgG 7S yang mempunyai waktu paruh sekitar 20 hari, IgG 5 S mempunyai waktu paruh lebih pendek yaitu 1236 jam sehingga tidak akan mengikat reseptor Fc yang menyebabkan imunosupresi.

\section{Daftar Pustaka}

1. Delire M. Immunoglobulins. Rationale for the clinical use of polyvalent intravenous immunoglobulins. Petersfield: Wrightson Biomedical Publishing Ltd, 1995. h. 29-65.

2. Parslow TG. The immune response. In: Stites DP, Terr Al, Parslow TG. Ed. Medical immunology. 9th. Ed. Connecticut: Appleton \& Lange, 1977. h. 63-73.

3. Kalbhein HJ. Therapy of sepsis with 5S-immunoglobulin. In: Dammaco F, ed. Immunoglobulins in therapy. International Symposium Immunoglobulins in therapy Vienna, November 1993. Maburg: Die Medizinische Verlagsgeseeschaft, 1995. h. 28-32.

4. Bellanti JA, Rocklin RE. Cell mediated immune reactions. In: Bellanti JA. Immunology III. Philadelphia: WB Saunders Company 1985. h. 181.

5. Abbas KA, Lichman AH, Rober JS. Cellular and molecular immunology. Philadelphia: WB Saunders Company 1991. h. 302-9. 